fats (derminols). A second sphere of development was in connexion with leather substitutes such as 'lefas', in which' leather fibres are bound together by resin emulsions, or plastic soling materials made from polyvinyl chloride (' $\mathrm{P}$ '-soles). The production of sausage casings, artificial fibre and surgical sutures from skin pieces by the Naturin-Werk represents a remarkable piece of chemical engineering. An important factor in the progress of the German leather industries has been the benefit which they have received from research and development in the German chemical industry, which systematically seeks new uses for the great variety of materials, intermediates, by-products and waste products which it produces. The high standard of technical management in the leather industry secures that these developments are absorbed and applied by the industry.

\section{The Wellcome Research Library}

The Wellcome Foundation has given $£ 80,000$ to the Royal Society of Medicine in order to enlarge the accommodation of the Library of the Society, and to provide endowment for the purchase of books and periodicals from such of the capital of the gift as is not expended on the structural alterations and the equipment necessary to the enlargement. The extension of the present Library is to be named 'The Wellcome Research Library' and it is left to the representatives of the Royal Society of Medicine in collaboration with the Wellcome Trustees to work out an application of the gift which shall preserve the conditions of the Trust and give the maximum effective benefit to the work of the Library of the Royal Society of Medicine. This problem will clearly resolve itself into details of how best to provide the accommodation both for more readers in the Library as well as for the books, while increasing the efficiency of the extensive and complex library service of the Society, without impairing the working of the many other activities of the Society conducted in the building. Enlargement of the House will be necessary, and the Trustees envisaged this in making the gift. Plans have been prepared and are now under consideration.

\section{Adventure in Engineering}

'Commemoration DaY' at the Imperial College of Science and Technology, London, was observed on October 27. After an inter-denominational service at Holy Trinity Church, Prince Consort Road, the chairman of the governing body, Viscount Falmouth, the rector, Sir Roderic Hill, the deans, staff and students proceeded to the Great Hall of the Imperial Institute for the ceremony of presentation of diplomates. Following the reception of the new diplomates of the Imperial College, and those of the Royal College of Science, the Royal School of Mines, and the City and Guilds of London Institute, and the presentation of scrolls to the honorary fellows elected during the past year, the 'distinguished visitor', Sir Bruce White, addressed the gathering. Referring to his student days at the City and Guilds College, then known as the Central Technical College, Sir Bruce commented on the great improvement in facilities and equipment that had meantime been achieved. However, despite wider and more intense studies, it seemed to him that engineers of the older generation would leave a deeper mark on the world than would those of to-day; they had vision and initiative which they did not fear to use. Nowadays the incursion of politics into engineering is leading to domination by committees, so that whereas the successful discharge of responsibilities should be the highest aim of all engineers, initiative is in fact being curbed, and responsibility of the individual is escaped or denied. Such a policy contributes to the astronomical cost of some public works to-day. Sir Bruce White advised engineering students to dismiss from their minds the 'safety first' attitude, to scorn to achieve success by an excessive margin of safety, and readily to accept an opportunity of gaining experience abroad. Experience should be sought in many fields of engineering practice, and to that end they should, while still young, be ready to move freely from one employment to another. Life is ambition, and security should not be sought at an early age; ambition kept always before them would in due time find its outlet and fulfilment. In the evening the laboratories and libraries of the Royal College of Science were open to visitors who, with the aid of senior students, were able to inspect and discuss the application of installations, instruments, and apparatus in current use in the teaching and research laboratories of the College.

\section{Ophiuroidea of the Hawaiian Islands}

Bulletitn 195 of the Bernice P. Bishop Museum, Honolulu ("Ophiuroidea of the Hawaiian Islands"; pp. 133 ; 1949), in which Austin H. Clark describes new ophiuroid fauna, is the final report on the echinoderms collected by the United States Fisheries steamer Albatross in 1902 and makes a valuable addition to the knowledge of Pacific ophiuroids. Besides the purely systematic description of Hawaiian ophiuroids, which includes the diagnoses of a number of new species, there is an interesting appendix on the general echinoderm fauna of the Hawaiian Islands. In this the writer has analysed the shore catches from different islands as well as the offshore catches, which are recorded under station numbers. The echinoderm fauna of the Hawaiian Islands lies on the periphery of the Indo-Pacific region, and some of the component echinoderms have become modified to form separate species. Although the fauna shows a Japanese element, especially among the sea urchins, brittle-stars and crinoids, the writer points out that this does not constitute evidence pointing to a direct past faunal connexion between southern Japan and the Hawaiian area; the species common to these two regions may, in fact, have reached them by separate routes from the Indo-Pacific faunal centre.

\section{Contributions to Embryology}

Vox. 33 of "Contributions to Embryology" maintains the very high standard which always characterizes this journal ("Contributions to Embryology", 33, Nos. 213-221, Publication 583. Pp. iii $+186+34$ plates. Washington, D.C. : Carnegie Institution, 1949. 8.50 dollars). It comprises a series of papers on the reproductive organs; a series on embryology ; and one anatomical paper by Adolph H. Schultz on "The Palatine Ridges of Primates". The series on reproduction includes a monograph by S. R. M. Reynolds on the changes which occur in the uterine vessels of pregnant rabbits; a paper by Elizabeth M. Ramsey on the vessels of the endometrium in the pregnant rhesus monkey; and a short paper by S. H. Sturgis on the rate of follicular atresia in the ovaries of the rhesus monkey. The most striking of the embryological 